\title{
Hong Kong and Singapore
}

\author{
By Toh, Hai Leong \\ Fall 1996 Issue of KINEMA
}

\section{SINGAPORE AND HONG KONG FESTIVALS: DIVERSITY, CONTRAST AND SIMI- LARITY}

FROM the 1st Hong Kong International Film Festival (HKIFF) in 1977 with 27 films to this year's 20th HKIFF with some 200 films, the increase in the number of films shown has been more than seven-fold.

Case 2: In 1987, the 1st Singapore International Film Festival (SIFF) exhibited 50 films. In comparison, 90 movies were presented in 1996, a near two-fold increase. However, what the festival lacked in sheer quantity it made up for in quality.

The HKIFF is 11 years older than the latter. However, as the date of Hong Kong's cessation to China on 1st July 1997 draws nearer, the HKIFF looks increasingly set to transfer its authority and eclecticism to its Singapore counterpart.

Thus in this year's HKIFF (25th March to 9th April) and SIFF (4th to 20th April), prints were shared for mutual benefit and to give more exposure to worthy Asian films like Zhang Yuan's Sons (1996), a superb cinema-v,rit, story of a dysfunctional family in Beijing recalling the power of the raw Fassbinderian Fear Eats the Soul, Wan Jen's heartfelt Super Citizen Ko (1995) and others.

Philip Cheah, the SIFF programmer, believes in emphasizing Asian films and independent productions which do not fit into the Hollywood mould. The HKIFF and SIFF shared Wan Jen's Super Citizen Ko and Hsu Hsiao-ming's Heartbreak Island (1995), both powerful, leisurely-paced films about the traumatic political past. The SIFF managed to add another feather in its cap by acquiring Hou Hsiao-hsien's Good Men, Good Women (1995), the last part of his trilogy which began with City of Sadness (1989) and The Puppetmaster (1993).

Another gem in this year's SIFF was the White Balloon (1995) by Iranian director Jafar Panahi. The film won the Camera d'or at Cannes last year for its fine study of a little girl who is searching for her lost money in the confusion of a bustling Tehran.

Politically, Singapore has an advantage over Hong Kong. It does not have to contend with pressures from the Mainland Chinese authorities. Over the past two years in the British colony, pressures have been put to bear on all the Mainland Chinese entries in the HKIFF. This has resulted in the withdrawal of several Mainland Chinese films, including Sherwood Xuehua Hu's Warrior Lanling (1996), Lu Wangping's The Story of Wan Laobai (1996), a video work about a peasant folk artist in northeast China. Even the Hong Kong-Chinese co-production, The King of Masks (1995) by renowned former director of the Xian film studio Wu Tianming, slotted to be the prestigious closing feature, was axed (two screenings).

Hsu Hsiao-ming's emotive film, Heartbreak Island replaced the first screening and it was left to Edward Yang's Mahjong (1996), a convoluted and disappointing film about modern Taipei's aimless youths to close the festival.

The Hong Kong International Film Festival has shown that it has come of age. Critics feel that next year will be its last and perhaps most glorious season. After that it is anybody's speculation. Furthermore the resignation of the astute Asian film programmer, Ms. Wong Ain-ling at the end of April 1996, has created a vacuum that is almost impossible to fill.

Other films that have antagonised the Mainland authorities are unapproved works by the Sixth Generation stalwarts. The blackest sheep is Zhang Yuan whose The Square already raised eyebrows last year and whose recent picture Sons (1996) about a family of alcoholics in Beijing is considered most undesirable by Chinese officials. 
Equally unwanted is Wu Wenguang's 1990 re-edited 70-minute version of Bumming in Beijing-The Last Dreamers, a companion piece to his 170-minute video At Home in the World (1995). In the latter the director portrays his provincial artist friends and their families overseas in Bologna, Paris, Salzburg and Palo Alto.

Even more politically inflaming is the massive 189-minute documentary, The Gate of Heavenly Peace (1995) by Carma Hinton and Richard Gordon which chronicles the events leading to and the aftermath of the June 1989 Tiananmen massacre. This film makes no heroes out of the pro-democracy protagonists but shows both sides of the conflict. In the end, fanaticism and extremism carry the day and the logical conclusion is a bloodbath. SIFF did not have the first showing of this documentary which was already shown on television and video.

However, the Singapore festival had a good line-up of Japanese films, including Ataru Oikawa's The Boy Made in Japan (1995), Shinya Tsukamoto's Tokyo Fist (1995), Kaizo Hayashi's The Breath (1995) and Ryosuke Hashiguichi's film on homosexuality Like Grains of Sand (1995), all of which kept the viewers thoroughly entertained.

On the other hand, Hongkong presented only two Japanese films: the snail-paced Maborosi (1995) by Hirokazu Kore-eda and Makoto Shinozaki's Oakeri (1995). The former concerns the guilt complex of Yumiko over her grandmother while the latter is about an ignored housewife Yuriko who descends into paranoid schizophrenia.

In addition, the SIFF presented an Icelandic-Japanese co-production Cold Fever (1995) by Fridrik Thor Fridrikson, a warm and affirmative film about a Tokyo Fish Company employee Atsushi (with an understated performance by Masatoshi Nagashe of Mystery Train fame) who sacrifices his vacation in Hawaii to go to "this very strange country," Iceland, to perform a memorial service in a remote corner of that frozen wasteland where his parents died. Atsushi's bizarre adventures include an encounter with a woman photographer who has a morbid penchant for taking funeral pictures, an American couple who robs a convenience store and steals his bone-shaking Citroën.

Hongkong was not to be outdone by such coups. Its Hong Kong Panorama, a well-chosen selection of eight films from recent production confirms that despite the alarming state of decline of the HK film industry, superb works are still being produced. Among them are Jaime Luk's Cold Fish (1995), a thriller-comedy about two contentious cops in Tai-O in search of a murderer and Tsui Hark's masterful work The Blade (1995), an exotic and visually stunning sword fighting extravaganza modelled after Chang Che's 1967 Onearmed Swordsman. Other noteworthy films were Wong Kar-wai's avant-garde movie Fallen Angels (1995) about a jaded hitman (Leon Lai), his lover who arranges his killing and cleans up after the job (Michelle Reis), a mute (Aniki Jin Chengwu) whose performance saves this brooding film from sheer ennui and Derek Yee's Full Throttle (1995) with Andy Lau as a racing ace who fails to realise his full potential due to a traumatic accident.

The Rediscovering Korean Classics' Retrospective brought in twelve great South Korean films made between the 1960s and 1980s. Among them were the successful Deep Blue Night (1984) by Bae Chang-ho and two 1961 masterpieces: Sin Sang-ok's The Guest and My Mother; Yu Hyun-mok's Aimless Bullet, three films by the dean of Korean cinema, Im Kwon-taek: Tchakko (1980), The Misty Village (1982) and Tickets (1986).

Both Singapore and Hongkong shared two big surprises -- one from Indonesia by Garin Nugroho called ...And the Moon Dances (1995), an enchanting film about a traditional song teacher and his two proteges, an aspiring composer and a young lady in search of her identity. The other surprise was the Korean movie A Single Spark (1995), Park Kwang-su's new film based on a true story of labour leader Jeon Tae-Il who burned himself to death in 1970. The only criticism that can be levied on Spark is that his hero is too angelic and self-sacrificing to be truly human.

Contemporary Korean cinema shows that it is still a powerful force to be reckoned with. This is demonstrated by a scorching debut by Lee Min-yong. His A Hot Roof (1995) literally sizzles. Set in Seoul's burning summer heat, ten women get even with a macho husband and then they take to the roof to make their stand. The film is impressive for being made by a male director who shows a strong feminist slant, rare indeed in Korean cinema. 
Seen in competitive light, the two festivals seem to be heading for a showdown. But a closer look reveals that their respective programmers -- Philip Cheah in Singapore and Li Cheuk-to and Wong Ain-ling in Hong Kong agree on what constitutes good cinema.

The two parties are also receptive to promising young Asian directors whose works were this year represented by Malaysian entries (shared between HKIFF and SIFF). Mahadi J. Murat's excellent Dear Salmah (1995) and U-Wei bin Haji Saari's The Arsonist (1994) surprised many critics and guests of the 20th HKIFF. These were refreshing films whose universal perspective transcended their national subject matter. The sheer force of their artistry and understatement enabled them to address the human condition.

As noted at the beginning of this report, Singapore is the likely successor of the Hong Kong International Film Festival. But it cannot be excluded that after next year's "last" HKIFF its perceptive programmers would simply emigrate and re-appear at some North American or European festival enriching them with an emphasis on Asian cinema.

\section{Author Information}

TOH Hai Leong is a Singapore-based freelance film critic and filmmaker (Zombie Dogs, 2005) who writes for independent film publications such as Screen International and World Paper. He has covered the Hong Kong International Film Festival since 1985 and specializes in the cinemas of Hong Kong, Taiwan, China, Korea and Japan. 